\title{
EFEKTIFITAS PENURUNAN SUHU TUBUH MENGGUNAKAN KOMPRES HANGAT DAN WATER TEPID SPONGE DI RUMAH SAKIT DKT TK IV 02.07.04 BANDAR LAMPUNG
}

\author{
Linawati Novikasari', Edita Revine Siahaan², Maryustiana ${ }^{3}$
}

1Fakultas Kedokteran, Program Studi IImu Keperawatan, Universitas Malahayati Bandar Lampung, Indonesia. Email: Linawatinovikasari@malahayati.ac.id 2Akademi Keperawatan Bunda Delima Bandar Lampung, Indonesia.

Email: Editasiahaan@bundadelimalampung.ac.id

${ }^{3}$ Rumah Sakit. DKT Bandar Lampung, Indonesia.

\section{ABSTRACT: NURSING MANAGEMENT OF FEVER IN CHILDREN}

Background: Compresses is a method to reduce body temperature when have a fever. Tepid sponging is an intervention to wipe the whole body with warm water using a washcloth.

Purpose: In the study it was found to be effective in decreasing body temperature between warm compresses and water tepid sponges on children with fever in pediatric ward, DKT TK IV 02.07.04 Hospital Bandar Lampung in 2017.

Methods: Types of quantitative research with Quasi Experiment approach with samples as many as 80 clients. Accidental sampling techniques. Retrieving data using observation sheets, data analysis techniques using statistical independent $t$ tests.

Results: The average temperature value was known before warm compresses $38.7^{\circ} \mathrm{C}$, after warm compresses $37.7^{\circ} \mathrm{C}$, the average temperature value before water tepid sponge $38.6^{\circ} \mathrm{C}$, after water tepid sponge $37.4^{\circ} \mathrm{C}$, There is an influence between before and after warm compresses with different mean is $0.89^{\circ} \mathrm{C}$. The results of statistical tests obtained $p$-value $0,000<0.05$. There are influences before and after the water tepid sponge with different mean is $1.2^{\circ} \mathrm{C}$. The results of the statistical test obtained $p$-value $0,000<0.05$.

Suggestion: To health workers, the need for socialization of parents regarding the handling of fever children using warm compresses in the hospital or at home.

\section{Keywords: Body temperature, warm compresses, water tepid sponge}

Pendahuluan: Kompres adalah salah satu metode fisik untuk menurunkan suhu tubuh bila mengalami demam. Tepid sponging merupakan tindakan untuk mengelap sekujur tubuh dengan air hangat menggunakan waslap. Tujuan : Pada penelitian diketahui efektifitas penurunan suhu tubuh antara kompres hangat dan water tepid sponge pada Klien anak dengan demam di ruang anak rumah sakit DKT TK IV 02.07.04 Bandar Lampung Tahun 2017.

Metode : Jenis Penelitian kuantitatif dengan pendekatan Quasi Experiment dengan sampel sebanyak 80 klien. Pengambilan sampel dengan teknik accidental Sampling. Pengambilan data menggunakan lembar observasi, Teknik analisis data menggunakan uji statistik uji t independent.

Hasil penelitian: Diketahui rata-rata nilai suhu sebelum kompres hangat $38,7^{\circ} \mathrm{C}$, setelah kompres hangat $37,7^{\circ} \mathrm{C}$, rata-rata nilai suhu sebelum water Tepid sponge $38,6^{\circ} \mathrm{C}$, setelah water Tepid sponge $37,4^{\circ} \mathrm{C}$, Ada pengaruh antara sebelum dan sesudah kompres hangat dengan beda mean adalah $0,89^{\circ} \mathrm{C}$. Hasil uji statistik didapatkan nilai $p$-value $0,000<0,05$. Ada pengaruh sebelum dan sesudah water Tepid sponge dengan beda mean adalah $1,2^{\circ} \mathrm{C}$. Hasil uji statistik didapatkan nilai $p$-value $0,000<0,05$.

Saran: Kepada tenaga kesehatan perlunya diadakan sosialisasi pada para orang tua tentang penanganan anak demam menggunakan kompres hangat baik di lingkup rumah sakit maupun di lingkup komunitas.

\section{Kata kunci : Suhu tubuh, kompres hangat, water tepid sponge}

\section{PENDAHULUAN}

Demam terjadi karena ketidak mampuan mekanisme kehilangan panas untuk mengimbangi produksi panas yang berlebih sehingga terjadi peningkatan suhu tubuh. Suhu adalah perbedaan antara jumlah panas yang dihasilkan tubuh dengan jumlah panas yang hilang ke lingkungan luar. Mekanisme kontrol suhu inti (suhu dalam jaringan) tetap konstan walaupun suhu permukaan berubah sesuai aliran darah ke kulit dan jumlah panas yang hilang ke lingkungan luar. Karena perubahan tersebut, suhu normal pada manusia dimana jaringan dan sel tubuh akan berfungsi secara optimal berkisar dari $36,5-37,5^{\circ} \mathrm{C}$ (Potter \& Perry, 2011). Uraian di atas cukup 
EFEKTIFITAS PENURUNAN SUHU TUBUH MENGGUNAKAN KOMPRES HANGAT DAN WATER TEPID SPONGE DI RUMAH SAKIT DKT TK IV 02.07.04 BANDAR LAMPUNG

menjelaskan bahwa ketika terjadi perubahan suhu tubuh, seperti suhu tubuh menurun kurang dari $36,5^{\circ} \mathrm{C}$ yang disebut dengan hipotermia ataupun naik lebih dari $37,5^{\circ} \mathrm{C}$ yang disebut dengan hipertermi atau demam (Bardu, 2014).

Demam merupakan suatu keadaan suhu tubuh diatas normal sebagai akibat peningkatan pusat pengatur suhu dihipotalamus. Sebagian besar demam pada anak merupakan akibat dari perubahan pada pusat panas (termoregulasi) di hipotalamus. Penyakit - penyakit yang ditandai dengan adanya demam dapat menyerang system tubuh. Selain itu demam mungkin berperan dalam meningkatkan perkembangan imunitas spesifik dan nonspesifik dalam membantu pemulihan atau pertahanan terhadap infeksi (Permatasari, 2013).

Badan Kesehatan Dunia (WHO) memperkirakan jumlah kasus demam di seluruh Dunia mencapai 16 - 33 juta dengan 500 - 600 ribu kematian tiap tahunnya (Setyowati, 2013). Data kunjungan ke fasilitas kesehatan pediatrik di Brazil terdapat sekitar 19\% sampai 30\% anak diperiksa karena menderita demam.

Di Indonesia penderita demam sebanyak $465(91.0 \%)$ dari 511 ibu yang memakai perabaan untuk menilai demam pada anak mereka sedangkan sisanya 23,1 saja menggunakan thermometer (Setyowati, 2013). Data Dinas Kesehatan Provinsi Lampung tahun 2013 menyebutkan bahwa demam pada anak usia 1- 14 tahun mencapai 4.074 anak dengan klasifikasi 1.837 anak pada usia 1-4 tahun, 1.192 anak pada usia 5-9 tahun dan 1.045 anak pada usia 10-14 tahun.

Penanganan demam terbagi menjadi dua tindakan yaitu tindakan farmakologis dan non farmakologis. Tindakan farmakologis yaitu tindakan pemberian obat sebagai penurun demam atau yang sering disebut dengan antipiretik. Tindakan non farmakologis adalah tindakan penurunan demam dengan menggunakan terapi fisik seperti menempatkan anak di ruang bersuhu dan bersirkulasi baik, mengganti pakaian anak dengan pakaian yang tipis dan menyerap keringat, memberikan hidrasi yang adekuat, dan memberikan kompres (Hamid, 2011).

Kompres adalah salah satu metode fisik untuk menurunkan suhu tubuh bila mengalami demam. Salah satu metode kompres yang sering digunakan adalah pemberian tepid sponging (kompres hangat). Tepid sponging merupakan tindakan untuk menurunkan suhu tubuh saat demam yaitu dengan merendam anak di dalam air hangat, mengelap sekujur tubuh dengan air hangat menggunakan waslap, dan dengan mengompres pada bagian tubuh tertentu yang memiliki pembuluh darah besar (Bardu, 2014).

"Pengaruh tepid sponge terhadap penurunan suhu tubuh dan kenyamanan pada anak usia pra sekolah dan sekolah yang mengalami demam di ruang perawatan anak Rumah Sakit Muhammadiyah Bandung", mengungkapkan bahwa rata - rata penurunan suhu tubuh saat mendapatkan terapi tepid sponging adalah $0,97^{\circ} \mathrm{C}$ dalam waktu 60 menit (Setiawati, 2009).

"Pengaruh Kompres Hangat terhadap Perubahan Suhu Tubuh Pada Klien Anak Hipertermia di Ruang Rawat Inap RSUD Dr. Moewardi Sukoharjo." menunjukan bahwa tindakan kompres hangat efektif dalam penurunan suhu tubuh pada anak dengan hipertermia di Ruang Rawat Inap RSUD Dr. Moewardi ( Purwanti, 2006) . "Efektifitas Kompres Hangat dalam Menurunkan Demam Pada Klien Thypoid abdominalis di RSUD Gorontalo."Jenis penelitian ini adalah quasi eksperiment. Berdasarkan hasil penelitian dapat disimpulkan bahwa tindakan kompres hangat efektif dalam menurunkan demam pada klien thypoid abdominalis di RSUD Gorontalo (Mohammad, 2012).Berdasarkan pra survey yang dilakukan pada tanggal 5 - 7 Februari 2017, dari 6 orang anak yang mengalami demam secara keseluruhan hanya diberikan kompres hangat tidak diberikan kompres dengan Water Tepid Sponge. Dari hasil kompres hangat yang dilakukan sebanyak 2 orang terjadi penurunan suhu tubuh sebanyak $1^{\circ} \mathrm{C}$ dan 3 orang tidak terjadi penurunan $0,5^{\circ} \mathrm{C}$ dan 1 orang tidak terjadi penurunan suhu tubuh. Keluarga klien belum mengetahui kompres hangat dengan teknik Water Tepid Sponge dan di rumah sakit belum terdapat standar operasional prosedur tentang teknik Water Tepid Sponge, sehingga teknik Water Tepid Sponge memang belum dilakukan dalam penurunan demam anak.

\section{METODE PENELITIAN}

Jenis penelitian ini kuantitatif dengan rancangan Cross-sectional. Pengambilan sampel dengan secara Acidental Sampling. Waktu penelitian telah dilaksanakan dari tanggal 26 April - 7 Mei 2017 dan tempat penelitian di ruang Anak Rumah Sakit DKT TK IV 02.07.04 Bandar Lampung dengan sampel sebanyak 80 klien, dengan rincian sebagai berikut: kelompok intervensi yang diberi perlakuan kompres hangat sebanyak 40 klien, kelompok

Linawati Novikasari' Fakultas Kedokteran, Program Studi llmu Keperawatan, Universitas Malahayati Bandar Lampung, Indonesia. Email: Linawatinovikasari@malahayati.ac.id

Edita Revine Siahaan ${ }^{2}$ Akademi Keperawatan Bunda Delima Bandar Lampung, Indonesia.

Email: Editasiahaan@bundadelimalampung.ac.id

Maryustiana ${ }^{3}$ Rumah Sakit. DKT Bandar Lampung, Indonesia. 
EFEKTIFITAS PENURUNAN SUHU TUBUH MENGGUNAKAN KOMPRES HANGAT DAN WATER TEPID SPONGE DI RUMAH SAKIT DKT TK IV 02.07.04 BANDAR LAMPUNG

intervensi yang diberi perlakuan water tepid sponge sebanyak 40 klien. Teknik pengumpulan data menggunakan lembar observasi.

\section{HASIL PENELITIAN}

Tabel 1. Distribusi rata-rata suhu sebelum dan sesudah pemberian kompres hangat dan water tepid sponge

\begin{tabular}{ccccccc}
\hline Kompres hangat & $\mathbf{N}$ & Mean & Min & Max & SD & $95 \% \mathbf{C l}$ \\
\hline Sebelum & 40 & 38,605 & 37,8 & 39,6 & 0,6000 & $38,413-$ \\
Setelah & 40 & 37,715 & 36,8 & 39,0 & 0,5691 & 38,797 \\
& & & & & & $37,533-$ \\
Water tepid sponge & & & & & & \\
Sebelum & 40 & 38,615 & 37,8 & 39,6 & 0,6233 & $38,416-$ \\
Setelah & 40 & 37,405 & 36,5 & 39,0 & 0,5914 & 38,814 \\
& & & & & & \\
\hline
\end{tabular}

Berdasarkan tabel 1 diatas diketahui mean suhu sebelum kompres hangat $38,7^{\circ} \mathrm{C}$ dengan nilai min $37,8{ }^{\circ} \mathrm{C}$ dan $\max 39,6^{\circ} \mathrm{C}$ diyakini benar rata-rata suhu sebelum kompres hangat adalah $38,4^{\circ} \mathrm{C}$ sampai dengan $38,7^{\circ} \mathrm{C}$ dan mean suhu setelah kompres hangat $37,7^{\circ} \mathrm{C}$ dengan nilai $\min 36,8^{\circ} \mathrm{C}$ dan $\max 39,0^{\circ} \mathrm{C}$ diyakini benar ratarata suhu setelah kompres hangat adalah $37,5^{\circ} \mathrm{C}$ sampai dengan $37,8^{\circ} \mathrm{C}$ maka dapat disimpulkan ada perbedaan suhu pada kelompok yang diberi kompres hangat sebelum dan setelah perlakuan, diketahui mean suhu sebelum water Tepid sponge $38,6^{\circ} \mathrm{C}$ dengan nilai min $37,8^{\circ} \mathrm{C}$ dan max $39,6^{\circ} \mathrm{C}$ diyakini benar rata-rata suhu sebelum water Tepid sponge adalah $38,4^{\circ} \mathrm{C}$ sampai dengan $38,8^{\circ} \mathrm{C}$ dan mean suhu setelah water Tepid sponge $37,4^{\circ} \mathrm{C}$ dengan nilai min $36,5^{\circ} \mathrm{C}$ dan max $39,0^{\circ} \mathrm{C}$ diyakini benar rata-rata suhu setelah water Tepid sponge adalah $37,2^{\circ} \mathrm{C}$ sampai dengan $37,5^{\circ} \mathrm{C}$ maka dapat disimpulkan ada perbedaan suhu pada kelompok yang diberi water Tepid sponge sebelum dan setelah perlakuan.

Tabel 2. Uji Normalitas data

\begin{tabular}{ccccccc}
\hline Kompres hangat & $\mathbf{N}$ & Mean & Beda & SD & $\boldsymbol{p}$-value & Keterangan \\
\hline Sebelum & 40 & 38,605 & 0,89 & 0,6000 & 0,000 & Ada perbedaan \\
$\quad$ Sesudah & & 37,715 & & 0,5691 & & \\
Water tepid sponge & & & & & & \\
$\quad$ Sebelum & 40 & 38,615 & 1,21 & 0,6233 & 0,000 & Ada perbedaan \\
Sesudah & & 37,405 & & 0,5914 & & \\
\hline
\end{tabular}

Berdasarkan tabel 2. diatas masing-masing variabel mempunyai nilai skewness dan standar eror, bila nilai skewness di bagi standar erornya menghasilkan angka $\leq 2$, maka distribusi normal, bila data berdistribusi normal maka dapat dilanjutkan untuk uji (t dependen), dan uji ( $t$ independent).

Linawati Novikasari' Fakultas Kedokteran, Program Studi llmu Keperawatan, Universitas Malahayati Bandar Lampung, Indonesia. Email: Linawatinovikasari@malahayati.ac.id

Edita Revine Siahaan ${ }^{2}$ Akademi Keperawatan Bunda Delima Bandar Lampung, Indonesia.

Email: Editasiahaan@bundadelimalampung.ac.id

Maryustiana ${ }^{3}$ Rumah Sakit. DKT Bandar Lampung, Indonesia. 
EFEKTIFITAS PENURUNAN SUHU TUBUH MENGGUNAKAN KOMPRES HANGAT DAN WATER TEPID SPONGE DI RUMAH SAKIT DKT TK IV 02.07.04 BANDAR LAMPUNG

Tabel 3. Distribusi peningkatan suhu sebelum dan sesudah pada kelompok yang diberikan kompres hangat dan water tepid sponge

\begin{tabular}{lcccc}
\hline \multicolumn{1}{c}{ Variabel } & Skewness & Std. Error & Skewness - Std.Error & Ket \\
\hline Suhu sebelum kompres hangat & 0,047 & 0,374 & 0,125 & Normal \\
Suhu setelah kompres hangat & 0,125 & 0,374 & 0,334 & Normal \\
$\begin{array}{l}\text { Suhu sebelum pemberian water } \\
\text { Tepid sponge }\end{array}$ & 0,109 & 0,374 & 0,291 & Normal \\
$\begin{array}{l}\text { Suhu setelah pemberian water } \\
\text { Tepid sponge }\end{array}$ & 0,398 & 0,374 & 1,064 & Normal \\
\hline
\end{tabular}

Berdasarkan tabel 3. diatas diketahui kelompok kompres hangat sebanyak 40 responden dengan mean suhu kompres hangat pada saat sebelum adalah $38,6^{\circ} \mathrm{C}$ dengan standar deviasi $0,60^{\circ} \mathrm{C}$. Pada sesudah kompres hangat didapatkan hasil mean adalah $37,7^{\circ} \mathrm{C}$ dengan standar deviasi $0,56^{\circ} \mathrm{C}$. Terlihat nilai perbedaan antara sebelum dan sesudah adalah $0,89^{\circ} \mathrm{C}$. Hasil uji statistik didapatkan nilai $p$-value $0,000<0,05$ maka dapat disimpulkan ada perbedaan yang signifikan pada kelompok perlakuan yang diberi kompres hangat sebelum dan sesudah perlakuan. diketahui kelompok water Tepid sponge sebanyak 40 responden dengan mean suhu water Tepid sponge pada saat sebelum adalah $38,6^{\circ} \mathrm{C}$ dengan standar deviasi $0,62^{\circ} \mathrm{C}$. Pada sesudah water Tepid sponge didapatkan hasil mean adalah $37,4^{\circ} \mathrm{C}$ dengan standar deviasi $0,59^{\circ} \mathrm{C}$. Terlihat nilai perbedaan antara sebelum dan sesudah adalah $1,2^{\circ} \mathrm{C}$. Hasil uji statistik didapatkan nilai $p$-value $0,000<0,05$ maka dapat disimpulkan ada perbedaan yang signifikan pada kelompok perlakuan yang diberi water Tepid sponge sebelum dan sesudah perlakuan.

\section{PEMBAHASAN}

\section{Pengaruh kompres hangat}

Berdasarkan hasil penelitian diketahui mean suhu sebelum kompres hangat $38,7^{\circ} \mathrm{C}$ dengan nilai $\min 37,8{ }^{\circ} \mathrm{C}$ dan $\max 39,6{ }^{\circ} \mathrm{C}$ diyakini benar ratarata suhu sebelum kompres hangat adalah $38,4^{\circ} \mathrm{C}$ sampai dengan $38,7^{\circ} \mathrm{C}$ dan mean suhu setelah kompres hangat $37,7^{\circ} \mathrm{C}$ dengan nilai min $36,8^{\circ} \mathrm{C}$ dan max $39,0^{\circ} \mathrm{C}$ diyakini benar rata-rata suhu setelah kompres hangat adalah $37,5^{\circ} \mathrm{C}$ sampai dengan $37,8^{\circ} \mathrm{C}$ maka dapat disimpulkan ada perbedaan suhu pada kelompok yang diberi kompres hangat sebelum dan setelah perlakuan.

Demam terjadi karena ketidak mampuan mekanisme kehilangan panas untuk mengimbangi produksi panas yang berlebih sehingga terjadi peningkatan suhu tubuh. Suhu adalah perbedaan antara jumlah panas yang dihasilkan tubuh dengan jumlah panas yang hilang ke lingkungan luar. Mekanisme kontrol suhu inti (suhu dalam jaringan) tetap konstan walaupun suhu permukaan berubah sesuai aliran darah ke kulit dan jumlah panas yang hilang ke lingkungan luar. Karena perubahan tersebut, suhu normal pada manusia dimana jaringan dan sel tubuh akan berfungsi secara optimal berkisar dari $36,5-37,5{ }^{\circ} \mathrm{C}$ (Potter \& Perry, 2011). Saat dilakukan kompres dengan air hangat pusat pengatur suhu menerima informasi bahwa suhu tubuh sedang berada dalam kondisi hangat, maka suhu tubuh butuh untuk segera diturunkan. Apalagi, saat demam kita memang merasa kedinginan meskipun tubuh kita justru mengalami peningkatan suhu. Kompres air hangat memiliki beberapa keuntungan, disamping membantu mengurangi rasa dingin, air hangat juga menjadikan tubuh terasa lebih nyaman (Arianti, 2010).

Tindakan kompres hangat efektif dalam penurunan suhu tubuh pada anak dengan hipertermia di Ruang Rawat Inap RSUD Dr. Moewardi (Purwanti, 2006). Tindakan kompres hangat efektif dalam menurunkan demam pada klien thypoid abdominalis di RSUD Gorontalo (Mohammad, 2012).

Menurut pendapat peneliti kompres hangat merupakan metode untuk menurunkan suhu tubuh. Pemberian kompres hangat pada daerah aksila (ketiak) efektif karena pada daerah tersebut

Linawati Novikasari' Fakultas Kedokteran, Program Studi llmu Keperawatan, Universitas Malahayati Bandar Lampung, Indonesia. Email: Linawatinovikasari@malahayati.ac.id

Edita Revine Siahaan ${ }^{2}$ Akademi Keperawatan Bunda Delima Bandar Lampung, Indonesia.

Email: Editasiahaan@bundadelimalampung.ac.id

Maryustiana ${ }^{3}$ Rumah Sakit. DKT Bandar Lampung, Indonesia. 
EFEKTIFITAS PENURUNAN SUHU TUBUH MENGGUNAKAN KOMPRES HANGAT DAN WATER TEPID SPONGE DI RUMAH SAKIT DKT TK IV 02.07.04 BANDAR LAMPUNG

banyak terdapat pembuluh darah besar dan banyak terdapat kelenjar keringat apokrin yang mempunyai banyak vaskuler sehingga akan memperluas daerah yang mengalami vasodilatasi yang akan memungkinkan percepatan perpindahan panas dari dalam tubuh ke kulit. Lingkungan luar yang hangat akan membuat tubuh menginterpretasikan bahwa suhu di luar cukup panas sehingga akan menurunkan kontrol pengatur suhu di otak supaya tidak meningkatkan pengatur suhu tubuh lagi, juga akan membuat poripori kulit terbuka sehingga mempermudah pengeluaran panas dari tubuh.

\section{Pengaruh water Tepid sponge}

Berdasarkan hasil penelitian diketahui mean suhu sebelum water Tepid sponge $38,6^{\circ} \mathrm{C}$ dengan nilai min $37,8^{\circ} \mathrm{C}$ dan max $39,6^{\circ} \mathrm{C}$ diyakini benar rata-rata suhu sebelum water Tepid sponge adalah $38,4^{\circ} \mathrm{C}$ sampai dengan $38,8^{\circ} \mathrm{C}$ dan mean suhu setelah water Tepid sponge $37,4^{\circ} \mathrm{C}$ dengan nilai $\min 36,5^{\circ} \mathrm{C}$ dan $\max 39,0^{\circ} \mathrm{C}$ diyakini benar ratarata suhu setelah water Tepid sponge adalah $37,2^{\circ} \mathrm{C}$ sampai dengan $37,5^{\circ} \mathrm{C}$ maka dapat disimpulkan ada perbedaan suhu pada kelompok yang diberi water Tepid sponge sebelum dan setelah perlakuan

Demam merupakan suatu keadaan suhu tubuh diatas normal sebagai akibat peningkatan pusat pengatur suhu dihipotalamus. Sebagian besar demam pada anak merupakan akibat dari perubahan pada pusat panas (termoregulasi) di hipotalamus. Penyakit - penyakit yang ditandai dengan adanya demam dapat menyerang system tubuh (Penelitian, 2013).. Selain itu demam mungkin berperan dalam meningkatkan perkembangan imunitas spesifik dan nonspesifik dalam membantu pemulihan atau pertahanan terhadap infeksi. Terapi water Tepid sponge jika dilakukan dengan benar akan sangat efektif dalam menurunkan panas atau demam pada anak dengan cepat. Tepid sponging merupakan tindakan untuk menurunkan suhu tubuh saat demam yaitu dengan merendam anak di dalam air hangat, mengelap sekujur tubuh dengan air hangat menggunakan waslap, dan dengan mengompres pada bagian tubuh tertentu yang memiliki pembuluh darah besar (Bardu, 2014).
Pada prinsipnya pemberian Tepid sponge dapat menurunkan suhu tubuh melalui proses penguapan dan dapat memperlancar sirkulasi darah, sehingga darah akan mengalir dari organ dalam kepermukaan tubuh dengan membawa panas. Kulit memiliki banyak pembuluh darah, terutama tangan, kaki, dan telinga. Aliran darah melalui kulit dapat mencapai $30 \%$ dari darah yang dipompakan jantung. Kemudian panas berpindah dari darah melaui dinding pembuluh darah kepermukaan kulit dan hilang kelingkungan sehingga terjadi penurunan suhu tubuh (Potter \& Perry, 2011).

Nilai rata-rata suhu tubuh sebelum diberikan Tepid sponge sebesar $38,5^{\circ} \mathrm{C}$ dengan standar deviasi $0,4^{\circ} \mathrm{C}$. Nilai rata-rata setelah diberikan Tepid sponge sebesar $37,1^{\circ} \mathrm{C}$ dengan standar deviasi $0,5^{\circ} \mathrm{C}$.Sehingga dapat diketahui ada penurunan nilai rata-rata suhu tubuh sebesar $1,4^{\circ} \mathrm{C}$ (Maling, Haryani \& Arif, 2012). Ada pengaruh kompres Tepid sponge terhadap penurunan suhu tubuh pada pasien hipertermi. Rata - rata penurunan suhu tubuh saat mendapatkan terapi tepid sponging adalah $0,97^{\circ} \mathrm{C}$ dalam waktu 60 menit (Setiawati, 2009). Pengaruh kompres Tepid sponge hangat terhadap penurunan suhu tubuh anak umur 1 - 10 tahun dengan hipertermi, didapatkan hasil $p$ value $=$ 0,001 yang artinya ada pengaruh kompres Tepid sponge terhadap penurunan suhu tubuh pada pasien hipertermi (Maling, 2012) .

Menurut pendapat peneliti kompres water Tepid sponge dengan menggunakan air hangat lebih efektif dalam menurunkan demam pada pasien hipertermi. Dalam pelaksanaan terapi kompres Tepid sponge hangat penulis menggunakan air hangat dengan suhu $37^{\circ} \mathrm{C}$ karena pasien tidak merasa panas dan pasien mengatakan bahwa panasnya pas. Intervensi yang direncanakan dan dilakukan bertujuan setelah dilakukan tindakan keperawatan, suhu tubuh pada pasien dalam batas normal dengan kriteria hasil suhu tubuh menurun setidaknya $0,5^{\circ} \mathrm{C}-1,8^{\circ} \mathrm{C}$. Intervensi yang disusun adalah memantau suhu tubuh setiap 4 jam sesuai dengan kebutuhan yang rasionalisasinya digunakan untuk memantau terjadinya kenaikan suhu secara tiba-tiba pada pasien. Melakukan kompres water Tepid sponge hangat yang rasionalisasinya mandi air hangat membantu

Linawati Novikasari' Fakultas Kedokteran, Program Studi llmu Keperawatan, Universitas Malahayati Bandar Lampung, Indonesia. Email: Linawatinovikasari@malahayati.ac.id

Edita Revine Siahaan ${ }^{2}$ Akademi Keperawatan Bunda Delima Bandar Lampung, Indonesia.

Email: Editasiahaan@bundadelimalampung.ac.id

Maryustiana ${ }^{3}$ Rumah Sakit. DKT Bandar Lampung, Indonesia. 
peredaran darah tepi di kulit melebar, sehingga pori-pori menjadi terbuka yang selanjutnya memudahkan dalam pengeluaran panas dari tubuh. Dalam intervensi ini penulis melakukan kompres pada pasien dan mendapatkan evaluasi dari hasil tindakan bahwa setelah 15 menit dilakukan tindakan keperawatan

Pemberian kompres Tepid sponge dalam penelitian yang dilakukan ini terbukti dapat menurunkan demam atau suhu tubuh pada pasien. Hasil penelitian mendapatkan bahwa suhu tubuh pada pasien anak setelah pemberian kompres Tepid sponge hangat rata-rata dapat mengalami penurunan $1,21^{\circ} \mathrm{C}$. Waktu yang diperlukan untuk kompres berdasarkan penelitian ini relatif sangat singkat yaitu dalam waktu 15 menit. Pengaruh pemberian terapi kompres Tepid sponge hangat terhadap penurunan suhu tubuh pada pasien dengan hipertermia terbukti efektif dalam menurunkan suhu tubuh pada anak yang mengalami hipertermia.

\section{Perbedaan kelompok kompres hangat dan water tepid sponge}

Berdasarkan hasil penelitian diketahui kelompok kompres hangat dengan mean suhu kompres hangat pada saat sebelum adalah $38,6^{\circ} \mathrm{C}$ dan sesudah kompres hangat didapatkan hasil mean adalah $37,7^{\circ} \mathrm{C}$ terjadi penurunan adalah $0,89^{\circ} \mathrm{C}$. Hasil uji statistik didapatkan nilai $p$-value $0,000<0,05$ maka dapat disimpulkan ada perbedaan yang signifikan pada kelompok perlakuan yang diberi kompres hangat sebelum dan sesudah perlakuan. Pada kelompok water Tepid sponge suhu tubuh sebelum adalah $38,6^{\circ} \mathrm{C}$ dan adalah $37,4^{\circ} \mathrm{C}$ nilai perbedaan antara sebelum dan sesudah adalah $1,2^{\circ} \mathrm{C}$. Hasil uji statistik didapatkan nilai $p$-value $0,000<0,05$ maka dapat disimpulkan ada perbedaan yang signifikan pada kelompok perlakuan yang diberi water Tepid sponge sebelum dan sesudah perlakuan. Penurunan suhu tubuh lebih banyak terjadi pada klien yang dilakukan dengan teknik water Tepid sponge, dengan penurunan $1,21^{\circ} \mathrm{C}$ atau berbeda $0.32^{\circ} \mathrm{C}$. sehingga disimpulkan bahwa water Tepid sponge lebih baik jika dibandingkan dengan kompres hangat

Pemberian kompres hangat pada daerah tubuh akan memberikan sinyal ke hipothalamus melalui sumsum tulang belakang. Ketika reseptor yang peka terhadap panas dihipothalamus di rangsang, system efektor mengeluarkan sinyal yang memulai keringat dan vasodilatasi perifer.perubahan ukuran pembuluh darah diatur oleh pusat vasomotor pada medulla oblongata dari tangkai otak, dibawah pengaruh hipothalamik bagian anterior sehingga terjadi Vasodilatasi. Terjadinya vasodilatasi ini menyebabkan pembuangan/kehilangan energi/ panas melalui kulit meningkat (berkeringat), diharapkan akan terjadi penurunan suhu tubuh sehingga mencapai keadaan normal kembali (Mailing, Haryani, \& Arif, 2012).

Pemakaian kompres panas biasanya dilakukan hanya setempat saja pada bagian tubuh tertentu. Dengan pemberian panas, pembuluh-pembuluh darah melebar. Sehingga akan memperbaiki peredaran darah didalam jaringan tersebut. Dengan cara ini penyaluran zat asam dan bahan makanan ke sel-sel diperbesar dan pembuangan dari zat-zat yang dibuang akan diperbaiki. Jadi akan timbul proses pertukaran zat yang lebih baik. Aktifitas sel yang meningkat akan mengurangi rasa sakit dan akan menunjang proses penyembuhan luka, radang yang setempat seperti abses, bisulbisul yang besar dan bernanah, radang empedu, dan juga beberapa radang persendian. Pada otototot, panas memiliki efek menghilangkan ketegangan. Setelah suatu pemberian kompres panas dapat dilakukan latihan fisioterapi dengan lebih mudah pada seorang Klien/penghuni (Permatasari, 2013).

Kompres Tepid sponge adalah sebuah teknik kompres hangat yang menggabungkan teknik kompres blok pada pembuluh darah supervisial dengan teknik seka (Hamid, 2011). Kompres Tepid sponge ini hampir sama dengan kompres air hangat biasa, yakni mengompres pada lima titik (leher, 2 ketiak, 2 pangkal paha) ditambah menyeka bagian perut dan dada atau diseluruh badan dengan kain. Basahi lagi kain bila kering. Kompres Tepid sponge bekerja dengan cara vasodiltasi (melebarnya) pembuluh darah perifer diseluruh tubuh sehingga evaporasi panas dari kulit ke lingkungan sekitar akan lebih cepat, dibandingkan hasil yang diberikan oleh kompres hangat yang hanya mengandalkan reaksi dari stimulasi hipotalamus.. Kompres Tepid sponge ini sudah terbukti efektif untuk menurunkan

Linawati Novikasari' Fakultas Kedokteran, Program Studi llmu Keperawatan, Universitas Malahayati Bandar Lampung, Indonesia. Email: Linawatinovikasari@malahayati.ac.id

Edita Revine Siahaan ${ }^{2}$ Akademi Keperawatan Bunda Delima Bandar Lampung, Indonesia.

Email: Editasiahaan@bundadelimalampung.ac.id

Maryustiana ${ }^{3}$ Rumah Sakit. DKT Bandar Lampung, Indonesia. 
panas tubuh saat demam, bahkan lebih cepat daripada meminum obat penurun panas.

Tepid sponge lebih efektif menurunkan suhu tubuh anak dengan demam dibandingkan dengan kompres hangat disebabkan adanya seka tubuh pada tepid sponge yang akan mempercepat vasodilatasi pembuluh darah perifer diseluruh tubuh sehingga evaporasi panas dari kulit ke lingkungan sekitar akan lebih cepat dibandingkan hasil yang diberikan oleh kompres hangat yang hanya mengandalkan dari stimulasi hipotalamus.Perbedaan luas rasio body surface area dengan jumlah luas washlap yang kontak dengan pembuluh darah perifer yang berbeda antara terknik kompres hangat dan tepid sponge akan turut memberikan perbedaan hasil terhadap percepatan penurunan suhu responden pada kedua kelompok perlakuan tersebut (Wardiyah, 2016).

Tepid sponge hangat lebih efektif dari kompres hangat (Isnaeni, 2014). Penurunan suhu tubuh kelompok water Tepid sponge secara signifikan lebih cepat dibandingkan kelompok antipiretik(penurun panas) (Thomas, 2009). Kelompok water Tepid sponge lebih cepat menurunkan suhu tubuh dibandingkan dengan kelompok antipiretik (penurun panas) (Kusnanto, Widyawati \& Cahyanti, 2017).

Ada perbedaan penurunan suhu tubuh antara pemberian tepid sponging dan plester kompres dalam menurunkan suhu tubuh pada anak usia balita yang mengalami demam di Puskesmas Salaman 1 Kabupaten Magelang, dengan $p$-value 0.002 (a : 0.05) jumlah selisih penurunan suhu tubuh $0.41^{\circ} \mathrm{C}$ (Bardu, 2014). Adanya perbedaan penurunan suhu tubuh antara kompres hangat dengan mean $0,5{ }^{\circ} \mathrm{C}$ dan tepid sponge dengan mean $0,8^{\circ} \mathrm{C}$ ( $p$ value $<a, 0,003<0,05$ ) (Wardiyah, Setiawati \& Setiawan, 2016). Lebih efektif kompres water tepid sponge dalam menurunkan suhu tubuh anak demam, dibandingkan dengan metode kompres hangat (Isnaeni, 2014) .

Menurut peneliti kompres hangat dan water tepid sponge adalah suatu metode dalam penggunaan suhu hangat setempat yang dapat menimbulkan beberapa efek fisiologis seperti rasa nyaman, mengurangi atau membebaskan nyeri, mengurangi atau mencegah terjadinya spasme otot, memperlancar sirkulasi darah, merangsang peristatik usus, serta memberi rasa hangat. Pada kasus demam di sarankan untuk tidak menggunakan pakaian tebal ataupun selimut tebal karena hal ini tidak di butuhkan dan justru akan memperhambat proses pengeluaran panas dalam tubuh, pakaikan saja pakaian dengan kain tipis jika sangat mendesak (tubuh dalam keadaan sangat menggigil) karena pada dasarnya apabila tubuh menggigil ataupun sebaliknya berkeringat dalam suatu aktivitas, hal tersebut menandakan tubuh sedang dalam mempertahankan/ menyeimbangkan ketahanan suhunya. Selain itu klien dan keluarga untuk mengurangi ketebalan pakaian dan menjaga pakaian serta sprai tetap kering merupakan hal yang mendorong kehilangan panas melalui konduksi dan konveksi. Intervensi selanjutnya menginstruksikan klien dan keluarga untuk membatasi aktivitas fisik dan meningkatkan frekuensi periode istirahat yang rasionalisasinya aktivitas dan stres akan meningkatkan laju metabolisme, sehingga meningkatkan produksi panas. Menginstruksikan klien dan keluarga untuk meningkatkan masukan cairan oral $\pm 1000 \mathrm{ml}$ perhari dengan rasionalisasinya cairan yang hilang membutuhkan penggantian.Menganjurkan untuk mengurangi aktivitas fisik untuk membatasi produksi panas yang rasionalisasinya aktivitas dapat meningkatkan suhu tubuh.

Berdasarkan hasil penelitian dapat disimpulkan bahwa pemberian tepid sponge bath lebih efektif dalam menurunkan suhu tubuh anak dengan demam dibandingkan dengan kompres air hangat. Hal ini disebabkan adanya seka tubuh pada teknik tersebut akan mempercepat vasodilatasi pembuluh darah perifer di sekujur tubuh sehingga evaporasi panas dari kulit ke lingkungan sekitar akan lebih cepat dibandingkan hasil yang diberikan oleh kompres air hangat yang hanya mengandalkan reaksi dari stimulasi hipotalamus. Jumlah luas waslap yang kontak dengan pembuluh darah perifer yang berbeda antara teknik kompres air hangat dengan tepid sponge bath akan turut memberikan perbedaan hasil terhadap penurunan suhu tubuh pada kelompok perlakuan tersebut.

\section{SIMPULAN}

Berdasarkan hasil penelitian dan pembahasan diambil beberapa kesimpulan sebagai berikut

Linawati Novikasari' Fakultas Kedokteran, Program Studi llmu Keperawatan, Universitas Malahayati Bandar Lampung, Indonesia. Email: Linawatinovikasari@malahayati.ac.id

Edita Revine Siahaan ${ }^{2}$ Akademi Keperawatan Bunda Delima Bandar Lampung, Indonesia.

Email: Editasiahaan@bundadelimalampung.ac.id

Maryustiana ${ }^{3}$ Rumah Sakit. DKT Bandar Lampung, Indonesia. 
EFEKTIFITAS PENURUNAN SUHU TUBUH MENGGUNAKAN KOMPRES HANGAT DAN WATER TEPID SPONGE DI RUMAH SAKIT DKT TK IV 02.07.04 BANDAR LAMPUNG

Rata-rata nilai suhu sebelum kompres hangat adalah $38,7^{\circ} \mathrm{C}$ setelah kompres hangat $37,7^{\circ} \mathrm{C}$, rata-rata nilai suhu sebelum water Tepid sponge $38,6^{\circ} \mathrm{C}$ da setelah water Tepid sponge adalah $37,4^{\circ} \mathrm{C}$

Ada pengaruh antara sebelum dan sesudah kompres hangat dengan beda mean adalah $0,89^{\circ} \mathrm{C}$. Hasil uji statistik didapatkan nilai $p$-value $0,000<0,05$. Ada pengaruh sebelum dan sesudah water Tepid sponge dengan beda mean adalah $1,2^{\circ} \mathrm{C}$. Hasil uji statistik didapatkan nilai $p$-value $0,000<0,05$.

\section{SARAN}

Berdasarkan pada kesimpulan yang telah diuraikan oleh penulis diatas, saran yang mungkin dapat dijadikan pertimbangan dan masukkan bagi institusi kesehatan adalah sebagai berikut :

\section{Bagi Orang Tua Anak}

Perlu meningkatkan pengetahuan mengenai tehnik kompres hangat yang tepat sesuai dengan kondisi anaknya. Orang tua bisa memberikan watert epid sponge pada anaknya yang sedang demam ataupun kejang demam sebelum menjangkau pelayanan kesehatan lebih lanjut. Sedangkan pada anak yang menolak pemberian tepid sponge, pemberian kompres hangat bisa diberikan sebagai penggantinya.

\section{Bagi Instansi Terkait}

Mengingat telah terbukti bahwa kompres hangat Tepid sponge yang dilakukan pada anak dalam menurunkan suhu pada anak dengan demam hendaknya protap kompres hangat tepid sponge segera bisa diterapkan.

\section{DAFTAR PUSTAKA}

Arianti, I. (2010). Perbandingan Efektivitas Pemberian Kompres Hangat antara Daerah dahi dengan Axilla Terhadap Penurunan Suhu Tubuh pada Anak Hipertermi di RSUD Lanto Daeng Pasewang Kabupaten Jeneponto (Doctoral dissertation, Universitas Islam Negeri Alauddin Makassar).
Bardu, T. Y. (2014). Perbandingan EfektifitasTepid Sponging Dan Plester Kompres Dalam Menurunkan Suhu Tubuh Pada Anak Usia Balita Yang Mengalami Demam Di Puskesmas Salaman 1 Kabupaten Magelang.

Hamid, M. A. (2011). Keefektifan kompres tepid sponge yang ilakukan ibu dalam menurunkan demam pada anak: randomized control trial di Puskesmas Mumbulsari Kabupaten Jember (Doctoral dissertation, Universitas Sebelas Maret).

Isneini, M. (2014). Efektifitas PenurunanSuhu Tubuh Antara Kompres Hangat Dan Water Tepid Sponge Pada Pasien Anak Usia 6 Bulan-3 Tahun Dengan Demam Di Puskesmas Kartasura Sukuharjo. Jurnal ums. ac. id

Kusnanto, K., Widyawati, I. Y., \& Cahyanti, I. S. (2017). Efektifitas Tepid Sponge Bath Suhu $320 \mathrm{c}$ dan $370 \mathrm{c}$ dalam menurunkan suhu tubuh anak demam. Jurnal Ners, 3(1), 1-7.

Maling, B., Haryani, S., \& Arif, S. (2012). Pengaruh Kompres Tepid Sponge Hangat Terhadap Penurunan Suhu Tubuh Pada Anak Umur 1-10 Tahun Dengan Hipertermia (Studi Kasus Di RSUD Tugurejo Semarang). Karya Ilmiah.

Maling, B., Haryani, S., \& Arif, S. (2012). Pengaruh kompres tepid sponge hangat terhadap penurunan suhu tubuh pada anak umur 1-10 tahun dengan hipertermia (Studi Kasus Di RSUD Tugurejo Semarang). Karya IImiah.

Mohamad, F. (2012). Efektifitas kompres hangat dalam menurunkan demam pada pasien thypoid abdominalis di Ruang G1 Lt. 2 RSUD Prof. Dr. H. Aloei Saboe Kota Gorontalo. Jurnal Health and Sport, 5(01).

Penelitian, K. (2013). Aplikasi diagnosa gejala demam pada balita menggunakan metode certainty factor (cf) dan jaringan syaraf tiruan (jst).

Linawati Novikasari' Fakultas Kedokteran, Program Studi llmu Keperawatan, Universitas Malahayati Bandar Lampung, Indonesia. Email: Linawatinovikasari@malahayati.ac.id

Edita Revine Siahaan ${ }^{2}$ Akademi Keperawatan Bunda Delima Bandar Lampung, Indonesia.

Email: Editasiahaan@bundadelimalampung.ac.id

Maryustiana ${ }^{3}$ Rumah Sakit. DKT Bandar Lampung, Indonesia. 
EFEKTIFITAS PENURUNAN SUHU TUBUH MENGGUNAKAN KOMPRES HANGAT DAN WATER TEPID SPONGE DI RUMAH SAKIT DKT TK IV 02.07.04 BANDAR LAMPUNG

Permatasari, K. I. (2013). Perbedaan efektivitas kompres air hangat dan Kompres Air biasa terhadap penurunan suhu tubuh pada anak dengan demam di RSUD Tugurejo Semarang. Karya Ilmiah.

Potter, P. A., \& Perry, A. G. (2004). Fundamentals of nursing

Purwanti, S., \& Nur Ambarwati, W. (2008). Pengaruh kompres hangat terhadap perubahan suhu tubuh pada pasien anak Hipertermia di Ruang Rawat Inap RSUD Dr. Moewardi Surakarta.

Setiawati, T. (2009). Pengaruh tepid sponge terhadap penurunan suhu tubuh dan kenyamanan pada anak usia pra sekolah dan sekolah yang mengalai demam di ruang perawatan anak Rumah Sakit Muhammadiyah Bandung (Doctoral dissertation, Universitas Indonesia. Fakultas IImu Keperawatan).

Setyowati, L. (2013). Hubungan Tingkat Pengetahuan Orang Tua dengan Penanganan Demam pada Anak Balita di Kampung Bakalan Kadipiro Banjarsari Surakarta. Skripsi, STIKES PKU Muhamadiah.
Thomas, S., Vijaykumar, C., Naik, R., Moses, P. D., \& Antonisamy, B. (2009). Comparative effectiveness of tepid sponging and antipyretic drug versus only antipyretic drug in the management of fever among children: a randomized controlled trial. Indian Pediatrics, 46(2).

Wardiyah, A., Setiawati, S., \& Romayati, U. (2016). Perbandingan efektifitas pemberian kompres hangat dan tepid sponge terhadap penurunan suhu tubuh anak yang mengalami demam di ruang alamanda RSUD dr. H. Abdul Moeloek Provinsi Lampung Tahun 2015. Holistik Jurnal Kesehatan, 10(1), 36-44.

Wardiyah, A., Setiawati, S., \& Setiawan, D. (2016). Perbandingan efektifitas pemberian kompres hangat dan tepidsponge terhadap penurunan suhu tubuh anak yang mengalami demam RSUD dr. H. Abdul Moeloek Provinsi Lampung. Jurnal IImu Keperawatan, 4(1), 4456. 